\title{
Uji Aktivitas Anti-Hiperglikemik, dan Penghambatan Stres Oksidatif Ekstrak Etanol Daun Jeruk Nipis (Citrus aurantifolia) pada Tikus Diabetes yang Diinduksi Aloksan
}

\author{
Test of Anti-Hyperglycemic Activity, and Oxidative Stress Inhibition of Ethanol Extract of Lime \\ (Citrus aurantifolia) Leaf in Diabetes Rats Alloxan-Induced
}

\author{
Yithro Serang* dan Felisia Bani \\ Akademi Farmasi Nusaputera, Semarang \\ *Corresponding author: ithoserang@gmail.com
}

\begin{abstract}
ABSTRAK
Pada keadaan patologik seperti diabetes, peningkatan stress oksidatif dalam tubuh akan menyebabkan penurunan aktivitas antioksidan endogen dalam tubuh sehingga tubuh tidak mampu mendetoksifikasi radikal bebas dan mencegah kerusakan sel. Salah satu sumber antioksidan alami sebagai antidiabetes adalah daun jeruk nipis (Citrus aurantifolia). Tujuan penelitian ini adalah untuk mengetahui aktivitas anti hiperglikemia ekstrak etanol daun jeruk nipis dan aktivitas enzim antioksidan SOD dan GPX.

Penelitian ini adalah penelitian eksperimental laboratorium dengan menggunakan rancangan post test only group design. Subyek penelitian ini adalah 30 ekor tikus putih jantan galur Wistar yang dikondisikan DM tipe 2 dengan induksi aloksan. Tikus dikelompokkan menjadi 6 kelompok: kelompok I netral, kelompok II tanpa perlakuan, kelompok III kontrol positif glibenklamid $80 \mathrm{mg} / \mathrm{Kg}$ BB, Kelompok IV, V dan VI adalah kelompok perlakuan dengan dosis berturut-turut 62,5 mg/Kg BB, $125 \mathrm{mg} / \mathrm{Kg}$ BB dan $250 \mathrm{mg} / \mathrm{Kg}$ BB. Kemudian dilakukan uji aktivitas SOD dan GPX.
\end{abstract}

Kata kunci: Diabetes melitus tipe 2, Antioksidan, Citrus aurantifolia

\section{ABSTRACT}

In pathological state such as diabetes, increase of oxidative stress in the body will cause decrease in endogenous antioxidant activity in the body so that the body is unable to detoxify free radicals and prevent cell damage. One source of natural antioxidant as antidiabetic is lime (Citrus aurantifolia) leaf. The purpose of this study was to determine the anti-hyperglycemic activity of ethanol extract of lime leaf and activity of antioxidant enzymes SOD and GPX.

The study was an laboratory experimental research by using post test only group design. The subjects of this study were 30 male rats Wistar strain which conditioned diabetes type 2 with induction of alloxan. Rats were grouped into 6 groups: group I neutral, group II non-treated, group III positive control of glibenclamide $80 \mathrm{mg} / \mathrm{kg}$, Group IV, V and VI were the treated group with doses of $62.5 \mathrm{mg} / \mathrm{kg}, 125 \mathrm{mg} / \mathrm{kg}$ and $250 \mathrm{mg} / \mathrm{kg}$, respectively. Then conducted test of SOD and GPX activities.

Keywords: Diabetes mellitus type 2, Antioxidant, Citrus aurantifolia

\section{PENDAHULUAN}

Diabetes mellitus (DM) adalah sekelompok penyakit yang dikarakterisasi oleh tingginya level glukosa darah sebagai akibat dari penurunan kemampuan tubuh untuk memproduksi dan atau menggunakan insulin (American Diabetes Association, 2011). Penyakit DM dapat terjadi akibat kelainan sekresi insulin, kerja insulin, atau keduaduanya (Arisman, 2011). DM menjadi salah satu penyakit terbesar di dunia. WHO memperkirakan sekitar 347 juta orang di seluruh dunia mengidap diabetes. Diperkirakan bahwa pada ta- hun 2030, diabetes menjadi penyebab utama tujuh kematian di dunia. Jumlah kematian akibat diabetes diproyeksikan meningkat lebih dari 50\% dalam 10 tahun ke depan. Pada tahun 2005, diperkirakan 1,1 juta orang meninggal karena diabetes, hampir $80 \%$ diantaranya terjadi di negara berpenghasilan rendah dan menengah, dan setengah dari pada orang di bawah usia 70 tahun, 55\% dari kematian diabetes pada wanita. WHO memprediksi Indonesia sebagai negara no 4 di dunia dengan jumlah penderita DM sebesar 21,3 juta pada tahun 2030 setelah 
India, Cina, dan Amerika Serikat.

Penyakit DM dapat meningkatkan produksi radikal bebas oksigen melalui autooksidasi glukosa dan glikasi protein. Degradasi oksidatif dari radikal-radikal ini berperan dalam pembentukan produk peroksidasi lipid. Peningkatan kadar radikal oksigen reaktif ini disebabkan ketidaksempurnaan sistem pertahanan antioksidan atau ketidakmampuan kapasitas perbaikan kerusakan oksidatif. Pada pasien DM, hiperglikemia menginduksi terjadinya stres oksidatif. Stres oksidatif ini memicu terjadinya berbagai kerusakan sel (Monroy, 2013).

Peredaman stress oksidatif tersebut memerlukan antioksidan. Antioksidan adalah senyawa yang mampu menangkal atau meredam dampak negatif oksidan dalam tubuh. Antioksidan secara umum dikelompokkan menjadi antioksidan endogen dan eksogen. Antioksidan endogen yaitu sejumlah komponen protein dan enzim yang disintesis dalam tubuh yang berperan dalam menangkal oksidasi oleh radikal bebas. Antioksidan endogen dibagi menjadi 2 kelompok yaitu kelompok enzimatis (enzim superoksida dismutase (SOD), katalase, dan glutation peroksidase) dan non enzimatis (tokoferol, karotenoid, flavonoid, quinon, bilirubin, asam askorbat, asam urat, protein pengikat logam, dan protein pengikat heme) (Erejuwa, 2010). Antioksidan eksogen bersumber dari makanan, terdiri atas tokoferol (vitamin E), asam askorbat (vitamin C), karotenoid dan flavonoid. Antioksidan jenis eksogen ini dapat dimodifikasi dengan makanan dan suplemen.

Sel yang normal mempunyai sejumlah enzim pertahanan yang beraksi sebagai antioksidan endogen (katalase, glutation peroksidase dan superoksida dismutase) untuk mendetoksifikasi radikal bebas dan mencegah kerusakan sel. Kerentanan suatu jaringan terhadap kerusakan oksidatif tergantung pada mekanisme pertahanan oksidatifnya, antara lain oleh aktivitas dan kandungan enzim antioksidan endogen. Pada keadaan patologik seperti diabetes, peningkatan stress oksidatif dalam tubuh akan meningkatkan pemakaian enzim antioksidan intrasel sehingga menyebabkan penurunan aktivitas antioksidan endogen dalam tubuh. Adanya peningkatan suplai antioksidan yang cukup dalam tubuh akan membantu mengurangi resiko komplikasi pada penderita diabetes (Monroy, 2013).

Telah banyak dilakukan studi tentang antioksidan alami dan menunjukkan jika antioksidan alami juga mampu melindungi tubuh terhadap kerusakan yang disebabkan spesies oksigen reaktif dan mampu menghambat penyakit degeneratif. Beberapa penelitian telah menunjukkan bahwa senyawa fenolik seperti flavonoid mempunyai aktivitas antioksidan penangkap radikal. Senyawa golongan flavonol dan flavon menunjukkan sifat antidiabetes pada uji invivo pada tikus (Loizzo, 2011).

Banyak obat konvensional yang digunakan dalam menurunkan kadar gula darah namun memiliki efek samping seperti hipoglikemik dan penambahan berat badan (Aliyan, 2012). Oleh sebab itu banyak dilakukan penelitian-penelitian tanaman tradisional yang memiliki efek yang sama dengan obat sintetik namun memiliki efek samping yang jauh lebih ringan dibandingkan dengan obat konvensional (Purwanti, 2012).

Ekstrak etanol daun jeruk nipis (Citrus aurantifolia) dibuktikan memiliki efek antioksidan dengan metode DPPH (Fajarwati, 2013). Selain itu, penelitian Loizzo MR (2012) telah membuktikan ekstrak kulit dan daun jeruk nipis memiliki komposisi kimia yang memiliki aktifitas antioksidan dan antikolisneterase.

Tujuan penelitian yang akan dilakukan yaitu: 1. Untuk mengetahui aktivitas anti hiperglikemia ekstrak etanol daun jeruk nipis.

2. Untuk mengetahui kemampuan ekstrak etanol daun jeruk nipis dalam meningkatkan aktivitas enzim antioksidan SOD dan GPX.

3. Untuk mengetahui korelasi antara aktivitas anti hiperglikemia, antioksidan.

Hasil penelitian ini diharapkan dapat mem- 
berikan penjelasan zat aktif dan mekanisme kerja tanaman jeruk nipis dalam menurunkan kadar gula darah dan mencegah kerusakan pankreas pada pasien DM tipe 2. Hasil penelitian ini nantinya dapat digunakan dalam pemanfaatan sediaan obat tradisional antidiabetes dan sebagai terapi pencegahan terjadinya komplikasi yang disebabkan stres oksidatif yang diinduksi hiperglikemia.

\section{MATERI DAN METODE PENELITIAN}

\section{Pengambilan bahan}

Simplisia dibeli dalam keadaan segar di Bandungan, Semarang, selanjutnya dikeringkan dan dilakukan pembuatan serbuk dengan mengguna kan mesin serbuk dan diayak dengan mess no 40.

\section{Ekstraksi}

Ditimbang sejumlah $500 \mathrm{~g}$ simplisia kering, ditambah etanol 96\% (3 kali bobot serbuk) kemudian dimasukan ke dalam bejana maserasi selama 3 hari sambil sesekali diaduk. Cairan hasil ekstraksi disaring dengan kertas saring. Ampas dimaserasi lagi dengan pelarut etanol, dilakukan dengan cara yang sama dan diulangi beberapa kali hingga hasil maserat yang diperoleh telah jernih. Semua ekstrak dipekatkan dengan vakum evaporator.

\section{Pembuatan larutan aloksan dalam larutan salin $0,15 \mathrm{M}$}

Larutan aloksan digunakan untuk induksi diabetes terhadap tikus putih jantan galur Wistar yang telah dipuasakan semalam. Aloksan dilarutkan dalam salin $(0,15 \mathrm{M})$ dan diberikan intraperitoneal pada dosis $150 \mathrm{mg} / \mathrm{kg}$ bb.

\section{Penyiapan hewan uji}

Digunakan 30 ekor tikus putih jantan galur Wistar umur 16 minggu dengan berat antara 150250 gram, dipelihara dalam kondisi kandang yang terjaga tempratur suhu $21^{\circ} \mathrm{C}$ kelembapan $55 \%$ dan diberi pakan dan air ad libitum. Secara acak tikus dikelompokkan menjadi 6 kelompok. Setiap kelompok terdiri dari 5 ekor tikus dan akan mendapat perlakuan yang berbeda yaitu : kelompok I adalah kelompok netral. Tikus hanya mendapat sejumlah ekuivalen $\mathrm{CMC} \mathrm{Na}$, kelom- pok II adalah control negatif, tikus diinduksi aloksan tanpa perlakuan, kelompok III adalah control positif, tikus diinduksi aloksan dan diberi glibenklamid $80 \mathrm{mg} / \mathrm{Kg} \mathrm{BB}$, Kelompok IV, V dan VI adalah kelompok perlakuan. Tikus diinduksi dengan aloksan, dilanjutkan pemberian ekstrak etanol Daun jeruk nipis dengan dosis berturut-turut adalah $62,5 \mathrm{mg} / \mathrm{Kb} \mathrm{BB}, 125 \mathrm{mg} / \mathrm{Kb}$ $\mathrm{BB}$ dan $250 \mathrm{mg} / \mathrm{Kg}$ BB selama 28 hari.

\section{Pengujian aktivitas efek anti hiperglikemik}

Tikus ditimbang dan dikelompokkan, dipuasakan terlebih dahulu selama 16 jam. Tujuan penimbangan berat badan ini adalah untuk mengetahui pertambahan berat badan tikus selama perlakuan. Pada hari pertama dilakukan pengambilan darah awal untuk pengukuran kadar glukosa darah awal $\left(\mathrm{T}_{0}\right)$ sebelum tikus diberi perlakuan. Sampel darah diambil dari vena lateral ekor tikus dengan cara menusuk ekor tikus, kemudian darah diteteskan pada strip yang telah dipasang pada glukometer, ditunggu 11 detik dan sampel darah bisa terbaca. Pada hari itu juga diberikan larutan aloksan monohidrat $125 \mathrm{mg} / \mathrm{kg}$ bb tikus secara intraperitoneal. Setelah 4 hari induksi dengan larutan aloksan, hewan uji yang positif diabetes melitus (kadar gula darah $>200 \mathrm{mmHg}$ ) dikelompokkan kemudian diambil darahnya untuk pengukuran kadar glukosa darah hari pertama $\left(\mathrm{T}_{1}\right)$. Pengambilan darah dilakukan pada pembuluh darah ekor tikus.

Masing-masing kelompok diberi suspensi CMC 0,5\% (kontrol negatif), suspensi glibenklamid 0,45 mg/ kg bb tikus (kontrol positif), suspensi ekstrak etanol daun jeruk nipis dengan dosis berturut-turut adalah $62,5 \mathrm{mg} / \mathrm{Kb} \mathrm{BB}, 125$ $\mathrm{mg} / \mathrm{Kb} \mathrm{BB}$ dan $250 \mathrm{mg} / \mathrm{Kg}$ BB (kelompok perlakuan) selama 28 hari. Pengambilan darah dilakukan pada hari ke-7 (T2), hari ke-14 (T3), hari ke-21 (T4) dan hari ke-28 (T5).

\section{Pengujian aktivitas antioksidan}

Pada hari ke -28 tikus dikorbankan dengan pentobarbital Na. Hati diambil, dibersihkan, dikeringkan dan diproses untuk uji biokimia. Hati dihomogenkan dalam buffer posfat $50 \mathrm{nM}(\mathrm{pH}$ 
7,4) yang mengandung inhibitor protease, 0,2 mM PMSF dan $1 \mathrm{mM}$ EDTA, pada suhu $4^{\circ} \mathrm{c}$ selama 30 detik (2-15 detik dengan 15 detik interval pendinginan). Homogenat disaring dan filtrate disentrifuse pada $1088 \mathrm{~g}$ (pada $\mu$ max 108 $\mathrm{mm})$ selama 5 menit dalam kondisi dingin. Supernatan yang dihasilkan digunakan untuk pengukuran aktivitas enzim antioksidan.

\section{Analisis Hasil}

Data kuantitatif hasil penelitian dinyatakan sebagi rata-rata (mean) $( \pm)$ standar deviasi (SD). Signifikansi statistic dihitung dengan menggunakan analisis varians satu arah (ANOVA) dilanjutkan denga t-test. Data kualitatif diperoleh dari hasil gambar histopatologi jaringan pankreas dengan pewarnaan hematoxaline dan eosine dapat dilihat masa sel islet beta pankreas. Korelasi antara antioksidan, efek anti hiperglikemik, akan dilakukan dengan analisis uji korelasi taraf kepercayaan 95\%. Nilai-nilai yang dianggap signifikan secara statistic ketika P-nilainya kurang dari $0,05(\mathrm{p}<0,05)$.

\section{HASIL PENELITIAN DAN PEMBAHASAN Hasil Pemeriksaan Ekstrak Etanolik Daun Jeruk}

Hasil pemeriksaan ekstrak etanolik daun jeruk adalah bentuk kental (tidak dapat dituang), warna hijau pekat, dan rasa sepat.

\section{Identifikasi kandungan kimia}

Identifikasi ekstrak etanolik daun jeruk secara kualitatif dilakukan di Laboratorium Akademi Farmasi Nusaputera. Hasil identifikasi terhadap ekstrak etanolik daun jeruk menunjukkan adanya kandungan senyawa kimia berupa alkaloid dan flavonoid.

\section{Hasil Perhitungan Rata-rata Kadar Glukosa Darah Tikus}

Untuk melihat kemampuan ekstrak etanol daun jeruk nipis dalam menurunkan kadar glukosa darah, maka hewan uji akan diinduksikan agen diabetogenik yaitu aloksan secara intraperitoneal.
Aloksan dapat menyebabkan stres oksidatif pada sel $\beta$, demikian pula pasien menderita diabetes sering mengalami stres oksidatif (Halliwel dan Gutteridge 1994).

Pada awal penelitian, terlebih dahulu dilakukan pengukuran kadar glukosa darah pada hewan uji yaitu pada $T_{0}$ (5 hari sebelum perlakuan), dimana pengukuran kadar glukosa ini digunakan sebagai pembanding untuk melihat apakah berhasil atau tidaknya induksi streptozotosin pada hewan uji. Setelah itu, dilanjutkan dengan induksi aloksan secara intraperitoneal pada semua kelompok kecuali kelompok kontrol normal.

Pada hari ke-5 setelah induksi aloksan, kadar glukosa darah kembali diukur sebagai $\mathrm{T}_{1}$ untuk memastikan bahwa hewan uji telah mengalami DM. Kadar glukosa darah tikus yang telah mencapai 200 mg/dL diindikasikan sebagai keadaan hiperglikemia. Pada kelompok perlakuan terjadi peningkatan kadar glukosa darah tikus $>200 \mathrm{mg} / \mathrm{dl}$. Hal ini menunjukkan bahwa penginduksian agen diabetogenik berhasil dilakukan, dan tikus dapat dinyatakan DM.

Hasil pengukuran kadar glukosa darah tikus setelah diberikan sediaan uji selama 24 hari (T3) menunjukkan bahwa kelompok kontrol positif glibenklamid $0,45 \mathrm{mg} / \mathrm{kg}$ BB tikus memiliki nilai rata-rata penurunan kadar glukosa darah tertinggi, artinya kelompok kontrol positif memiliki aktivitas yang lebih tinggi terhadap penurunan kadar glukosa darah tikus, diikuti kelompok ekstrak etanol daun jeruk nipis $250 \mathrm{mg} / \mathrm{kg}$ BB tikus, kelompok ekstrak etanol daun jeruk nipis $125 \mathrm{mg} / \mathrm{kg}$ BB tikus, kelompok ekstrak etanol daun jeruk nipis $62,5 \mathrm{mg} / \mathrm{kg}$ BB tikus dan yang terendah adalah kelompok kontrol negatif CMC 0,5\%. Dari grafik Gambar 1 dapat dilihat bahwa kelompok ekstrak etanol daun jeruk nipis $250 \mathrm{mg} / \mathrm{kg}$ BB tikus memiliki aktifitas yang paling baik dalam menurunkan kadar glukosa darah, walaupun belum sebanding dengan kelompok kontrol positif. Hal ini menunjukkan bahwa besarnya dosis dapat mempengaruhi aktivitas antihiperglikemi. Pada penelitian ini, semakin besar dosis maka aktivitas 
antihiperglikeminya semakin baik.

Rata-rata penurunan kadar glukosa darah tikus setelah diberi sediaan uji dapat dilihat selengkapnya pada Lampiran 16. Glibenklamid telah diketahui sebagai obat antidiabetik oral yang mampu menurunkan kadar glukosa darah dengan cara menstimulasi sel $\beta$ pankreas untuk melepaskan insulin yang tersimpan dan meningkatkan sekresi insulin akibat rangsangan glukosa (Soegondo, 2005). Hasil uji statistik rata-rata penurunan kadar glukosa darah tidak terdistribusi normal, sehingga dilanjutkan menggunakan Kruskal-Wallis, dan diperoleh nilai Asymp. Sig. $<0,05$ yang menunjukkan bahwa ada perbedaan signifikan rata-rata penurunan kadar glukosa darah pada tiap kelompok. Dengan demikian dapat diketahui bahwa pemberian ekstrak etanol daun jeruk nipis dapat memberikan pengaruh dalam rata-rata penurunan kadar glukosa darah tikus yang di induksi aloksan

Ekstraksi dengan etanol akan mengekstraksi semua senyawa kimia/bioaktif yang terdapat pada daun jeruk nipis, diantaranya flavonoid, alkaloid dan saponin, dimana setiap senyawa tersebut mempunyai kemampuan untuk menurunkan kadar glukosa darah (Ambarwati et al, 2015). Berdasarkan tabel dibawah, dapat dilihat perubahan luas daerah dibawah kurva kadar glukosa darah tikus sebelum dan sesudah permberian sediaan uji ekstrak etanol daun jeruk nipis dihitung dari $\mathrm{T}_{0}$ sampai $\mathrm{T}_{4}$. Hasil perhitungan rata-rata AUC kadar glukosa darah memperlihatkan hu- bungan yang berbanding terbalik yaitu semakin kecil nilai AUC total maka efektifitas antihiperglikeminya semakin besar.

Berdasarkan luas $\mathrm{AUC}_{\text {total }}$ pada tabel di atas kadar glukosa darah pada seluruh kelompok perlakuan memberikan efek penurunan kadar glukosa darah setiap minggunya. Rata-rata luas $\mathrm{AUC}_{\text {total }}$ kelompok perlakuan berada di bawah 1 uas $\mathrm{AUC}_{\text {total }}$ kontrol negatif. Hal ini sesuai dengan pernyataan sebelumnya bahwa semakin kecil nilai AUC maka aktivitas antihiperglikeminya semakin baik. Diagram balok nilai rata-rata luas $\mathrm{AUC}_{\text {total }}$ dapat dilihat pada Gambar 2.

\section{Hasil Pengukuran Aktivitas Enzim SOD, dan GPx}

Kemampuan ekstrak etanol dan fraksi-fraksi ekstrak etanol daun jeruk nipis dalam meningkatkan aktivitas enzim antioksidan dapat dievaluasi dengan mengukur peningkatan kadar enzim SOD dan GPx pada darah tikus yang telah diberikan perlakuan selama 28 hari. Hasil pengukuran kadar SOD dan GPx dapat dilihat pada Lampiran 26-28. Nilai SOD dan GPx yang tinggi menunjukkan bahwa tikus berada dalam kondisi yang normal. Dari Tabel 2 terlihat bahwa kelompok kontrol normal adalah tikus yang sehat. Nilai SOD (\%) menyatakan jumlah anion superoksida yang berhasil dihambat, nilai GPx menyatakan jumlah enzim yang dibutuhkan untuk mengkatalisis oksidasi dari 1 nmol NADPH per menit dalam satu mg protein.

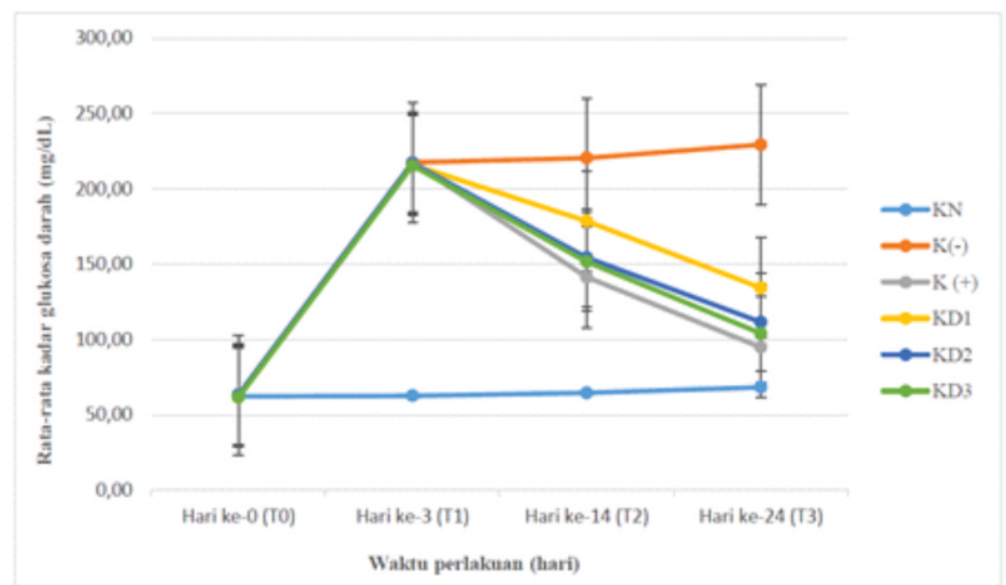

Gambar 1. Grafik pengaruh pemberian ekstrak etanol daun jeruk nipis selama 24 hari 
Tabel 1. Perhitungan AUC

\begin{tabular}{|c|c|c|c|c|c|c|c|}
\hline \multirow[b]{2}{*}{$\begin{array}{c}\text { Kelom } \\
\text { pok }\end{array}$} & \multirow[b]{2}{*}{$\begin{array}{c}\text { Kode } \\
\text { hewan }\end{array}$} & \multicolumn{6}{|c|}{ Perhitungan AUC } \\
\hline & & $\begin{array}{c}\text { Hari ke } \\
\mathbf{0 - 3}\end{array}$ & $\begin{array}{c}\text { Hari ke } \\
3-10\end{array}$ & $\begin{array}{c}\text { Hari ke } \\
\text { 10-17 }\end{array}$ & $\begin{array}{l}\text { Total } \\
\text { AUC }\end{array}$ & $\begin{array}{c}\text { Rata- } \\
\text { rata } \\
\text { AUC }\end{array}$ & SD \\
\hline \multirow{5}{*}{$\mathbf{K N}$} & I. 1 & 191,60 & 451,90 & 461,01 & 1104,52 & \multirow{5}{*}{1096,19} & \multirow{5}{*}{$\begin{array}{c}17,2 \\
4\end{array}$} \\
\hline & $\mathrm{I} .2$ & 188,16 & 451,50 & 477,77 & 1117,43 & & \\
\hline & I. 3 & 187,01 & 439,09 & 456,55 & 1082,65 & & \\
\hline & I.4 & 182,99 & 443,46 & 475,08 & 1101,53 & & \\
\hline & I.5 & 185,28 & 437,59 & 451,97 & 1074,84 & & \\
\hline \multirow{5}{*}{$\mathbf{K}(-)$} & II.1 & 425,01 & 1536,60 & 1599,03 & 3560,63 & \multirow{5}{*}{3529,43} & \multirow{5}{*}{$\begin{array}{c}33,7 \\
9\end{array}$} \\
\hline & II. 2 & 418,14 & 1523,65 & 1549,32 & 3491,11 & & \\
\hline & II. 3 & 411,78 & 1521,35 & 1572,44 & 3505,57 & & \\
\hline & II.4 & 422,73 & 1536,46 & 1562,50 & 3521,69 & & \\
\hline & II.5 & 427,93 & 1549,55 & 1590,65 & 3568,12 & & \\
\hline \multirow{5}{*}{$\mathbf{K}(+)$} & III.1 & 422,75 & 1268,88 & 836,08 & 2527,71 & \multirow{5}{*}{2504,67} & \multirow{5}{*}{$\begin{array}{c}40,4 \\
5\end{array}$} \\
\hline & III.2 & 427,91 & 1269,41 & 818,10 & 2515,42 & & \\
\hline & III.3 & 419,83 & 1248,56 & 824,02 & 2492,42 & & \\
\hline & III.4 & 423,84 & 1266,15 & 856,41 & 2546,41 & & \\
\hline & III.5 & 413,49 & 1227,97 & 799,90 & 2441,37 & & \\
\hline \multirow{5}{*}{ KD1 } & IV.1 & 411,22 & 1360,47 & 1092,06 & 2863,75 & \multirow{5}{*}{2894,27} & \multirow{5}{*}{$\begin{array}{c}57,0 \\
1\end{array}$} \\
\hline & IV.2 & 414,08 & 1361,97 & 1061,79 & 2837,83 & & \\
\hline & IV.3 & 412,37 & 1365,52 & 1081,22 & 2859,11 & & \\
\hline & IV.4 & 427,38 & 1410,91 & 1126,79 & 2965,08 & & \\
\hline & IV.5 & 419,89 & 1411,07 & 1114,60 & 2945,56 & & \\
\hline \multirow{5}{*}{ KD2 } & V.1 & 422,15 & 1295,63 & 923,65 & 2641,42 & \multirow{5}{*}{2650,08} & \multirow{5}{*}{$\begin{array}{c}36,7 \\
5\end{array}$} \\
\hline & V.2 & 416,96 & 1280,09 & 903,21 & 2600,25 & & \\
\hline & V.3 & 425,05 & 1303,53 & 908,68 & 2637,25 & & \\
\hline & V.4 & 418,73 & 1312,55 & 946,20 & 2677,48 & & \\
\hline & V.5 & 416,37 & 1306,97 & 970,66 & 2694,01 & & \\
\hline \multirow{5}{*}{ KD3 } & VI.1 & 418,71 & 1286,63 & 898,40 & 2603,74 & \multirow{5}{*}{2596,08} & \multirow{5}{*}{$\begin{array}{c}30,7 \\
3\end{array}$} \\
\hline & VI.2 & 409,49 & 1260,73 & 874,50 & 2544,72 & & \\
\hline & VI.3 & 416,35 & 1289,65 & 900,97 & 2606,96 & & \\
\hline & VI.4 & 416,98 & 1287,59 & 893,37 & 2597,94 & & \\
\hline & VI.5 & 417,62 & 1301,63 & 907,78 & 2627,03 & & \\
\hline
\end{tabular}

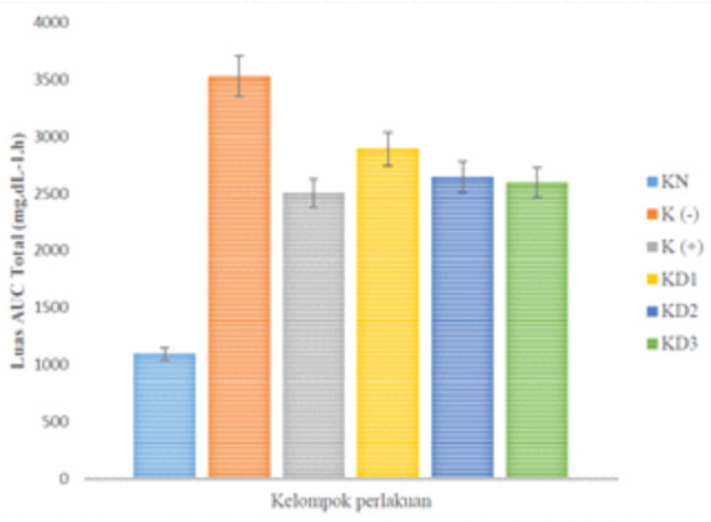

Gambar 2. Rata-rata luas AUCtotal (mg.dl-1.h) 
Tabel 2. Hasil rata-rata aktivitas SOD, dan GPx

\begin{tabular}{cccc}
\hline Kelompok & N & \multicolumn{2}{c}{ Hasil rata-rata aktivitas SOD, GPx \pm SD } \\
\cline { 3 - 4 } & & SOD $(\%)$ & GPx $(\mathrm{U} / \mathrm{mg})$ \\
\hline $\mathrm{KN}$ & 5 & $82,22 \pm 3,84$ & $74,08 \pm 1,22$ \\
$\mathrm{~K}(-)$ & 5 & $18,89 \pm 4,42$ & $20,99 \pm 1,48$ \\
$\mathrm{~K}(+)$ & 5 & $70,74 \pm 3,56$ & $71,77 \pm 1,81$ \\
$\mathrm{KD} 1$ & 5 & $37,41 \pm 4,79$ & $41,83 \pm 1,82$ \\
$\mathrm{KD} 2$ & 5 & $52,22 \pm 3,56$ & $53,09 \pm 1,48$ \\
$\mathrm{KD} 3$ & 5 & $58,89 \pm 3,56$ & $67,91 \pm 1,22$ \\
\hline
\end{tabular}

Keterangan:

$\mathrm{KN}=$ Kontrol normal

$\mathrm{K}(-)=$ Kontrol negatif $(\mathrm{CMC} 0,5 \%)$

$\mathrm{K}(+)=$ Kontrol positif (Glibenklamid $0,45 \mathrm{mg} / \mathrm{kg}$ BB tikus)

$\mathrm{KD} 1=$ Ekstrak etanol daun jeruk nipis dosis $62,5 \mathrm{mg} / \mathrm{Kb}$ BB tikus

$\mathrm{KD} 2=$ Ekstrak etanol daun jeruk nipis dosis $125 \mathrm{mg} / \mathrm{Kb} \mathrm{BB}$ tikus

$\mathrm{KD} 3=$ Ekstrak etanol daun jeruk nipis dosis $250 \mathrm{mg} / \mathrm{Kg}$ BB tikus

Selain itu, pada kondisi hiperglikemia, glukosa akan mengalami metabolisme melalui jalur alternatif yaitu jalur autooksidasi glukosa, serta glikasi dan pembentukan dikarbonil, dimana jalur ini akan menghasilkan radikal bebas hidroksil $\left(\mathrm{OH}^{-}\right)$dan radikal superoksida $\left(\mathrm{O}_{2}{ }^{-}\right)$. Pembentukan yang berlebih tersebut tidak dapat dinetralkan oleh enzim SOD dan GPx (Suarsana et al., 2011). Pada penelitian ini digunakan aloksan sebagai agen radikal bebas yang menyebabkan kerusakan oksidatif pada pankreas tikus. Keadaan hiperglikemia akan menyebabkan terjadinya pembentukan radikal bebas yang lebih tinggi. Pada kelompok kontrol negatif terjadi penurunan kadar SOD dan GPx.

Berdasarkan analisis statistik, kelompok kontrol positif menunjukkan peningkatan kadar yang signifikan $(\mathrm{p}>0,05)$. Glibenklamid bekerja dengan meningkatkan sekresi insulin dari pankreas yang menyebabkan intake glukosa darah meningkat sehingga kadar glukosa darah menjadi turun. Selain itu glibenklamid juga menyebabkan homeostasis pada pankreas berjalan baik, sehingga pertahanan enzim endogen dapat bekerja menetralisir radikal bebas (Kamlasi, 2015).

Hasil uji statistik menggunakan One Way Anova pada kadar SOD dan GPx juga menunjukkan bahwa semua kelompok perlakuan ekstrak etanol daun jeruk nipis memiliki perbedaan yang signifikan dengan kontrol negatif. Dengan demikian dapat diketahui bahwa pemberian ekstrak etanol daun jeruk nipis dapat memberikan pengaruh dalam peningkatan kadar SOD dan GPX. Penurunan stress oksidatif berarti menurunkan proses degenerasi sel $\beta$ pankreas sehingga akan mempercepat proses dari regenerasi sel $\beta$ pankreas.

Pada uji statistik, semua kelompok perlakuan ekstrak etanol daun jeruk nipis memiliki perbedaan secara signifikan dengan kelompok kon trol positif yaitu glibenklamid dan kelompok kontrol negatif. Hal ini menunjukkan bahwa statistik, kemampuan ekstrak etanol daun jeruk nipis belum bisa sebanding dengan kontrol positif (glibenklamid) dalam meningkatkan kadar SOD dan GPx. Namun, jika di lihat dari grafik rata-rata kadar SOD dan GPx, terlihat dosis yang paling besar yaitu dosis ekstrak etanol daun jeruk nipis dosis $250 \mathrm{mg} / \mathrm{Kg}$ BB tikus terjadi penurunan kadar SOD dan GPx yang signifikan. Hal ini sebanding dengan penurunan kadar glukosa darah, dimana pada dosis-dosis tersebut terjadi penurunan kadar glukosa yang signifikan.

Senyawa yang diduga memiliki aktivitas sebagai antioksidan yaitu flavonoid, alkaloid, dan saponin. Flavonoid memiliki potensi sebagai antioksidan karena memiliki gugus hidroksil yang terikat pada karbon cincin aromatik sehingga dapat menangkap radikal bebas yang dihasilkan dari rekasi peroksidasi lemak. Senyawa flavonoid akan menyumbangkan satu atom hydrogen untuk menstabilkan radikal peroksi lemak. 
Kemampuan flavonoid telah banyak diteliti belakangan ini, dan dimana salah satu kemampuan flavonoid dapat merubah atau mereduksi radikal bebas dan juga sebagai anti radikal bebas (Giorgio, 2000).

Mekanisme kerja saponin dalam menurunkan kadar glukosa darah yaitu dengan merubah struktur membran usus menjadi lebih permeabel terhadap makromolekul sehingga absorbsi terhadap mikromolekul seperti glukosa menjadi terhambat (Miura, 1996). Selain itu, saponin juga dapat menstimulasi pelepasan insulin dan menghambat pembentukan glukosa dalam aliran darah Reddy, 2012). Sedangkan menurut Bunting et al (2006), alkaloid dapat bekerja dengan menstimulasi hipotalamus untuk meningkatkan sekresi Growth Hormone Releasing Hormone (GHRH), sekresi Growth Hormone (GH) pada hipofise akan meningkat, dimana kadar $\mathrm{GH}$ yang tinggi akan menstimulasi hati untuk mensekresikan Insulin like Growth Factor-1 (IGF-1) yang mempunyai efek dalam menginduksi hipoglikemia dan menurunkan glukoneogenesis sehingga kadar glukosa darah dan kebutuhan insulin menurun.

Hasil fitokimia dari tanaman ekstrak daun jeruk nipis terdapat berbagai metabolit sekunder di antaranya flavonoid, alkaloid, dan saponin, dimana senyawa-senyawa ini dapat bertindak sebagai antihiperglikemia dan juga sebagai antioksidan (Loizzo, 2012).

\section{DAFTAR PUSTAKA}

[ADA]. 2011. Standards of medical care in diabetes, diabetes care. Supplement_1. American Diabetes Association Journal. Volume 34:512

[ADA]. 2012. Standards of Medical Care in Diabetes. American Diabetes Association Journal. Vol. 35.

Aliyan AH. 2012. Uji penghambatan aktivitas alfa glukosidase dan identifikasi golongan senyawa kimia dari fraksi aktif ekstrak biji mahoni. [Skripsi]. Jakarta: FMIPA, UI.

Arisman MB. 2011. Obesitas, Diabetes Millitus dan Dislipidemia Konsep, Teori dan Penanganan Aplikatif. Jakarta: EGC.

[Depkes]. 2000. Inventaris Tanaman Obat Indonesia (1). Jilid III. Jakarta: Departemen Kesehatan dan Kesejahteraan Sosial Republik Indonesia Badan Penelitian dan Pengembangan Kesehatan.

Erejuwa $\mathrm{O}$ et al. 2010. Antioxidant protective effect of Glibenclamide and Metformin in combination with honey in pancreas of Streptozotocin induced Diabetic rats. Int. J. Mol. Sci. 11: 2056-2066.

Fajarwati N. 2013. Uji Aktivitas Antioksidan pada Ekstrak Daun Jeruk Nipis (Citrus aurantifolia) dengan Menggunakan Metode DPPH. [Laporan Penelitian]. Jakarta: UIN Syarif Hidayatullah.

Harborne JB. 1987. Metode Fitokimia. Edisi II. Bandung: Institut Teknologi Bandung.

Ikawati Z. 2008. Pengantar Farmakologi Molekuler. Gadjah mada University Press. 25-26.

Loizzo MR, Tundis R, Bonesi M, Menichini F, De Luca D, Colica C. 2012. Evaluation of Citrus aurantifolia peel and leaves extracts for their chemical composition, antioxidant and anti-cholinesterase activities. J Sci Food Agric. 92 (15): 2960-7.

Monroy ML, Mejia CF. 2013. Oxidative stress in Diabetes Mellitus and the role of vitamins with antioxidant actions. Mexico Ntech. 9:210-215.

Reddy LJ, Jalli RD, Jose B, Gopu S. 2012. Evaluation of Antibacterial \& Antioxidant Activities of The Leaf Essential Oil \& Leaf Extract of Citrus Aurantifolia. Asian Journal of biochemical and Pharmaceutical Research. 2:346-53. 